\title{
University Student's Experiences with Online Synchronous Learning during Covid-19
}

\author{
Rasto $^{1}$, Sambas Ali Muhidin ${ }^{1}$, Tutik Inayati ${ }^{1}$, Marsofiyati ${ }^{2}$ \\ ${ }_{1}^{1}$ Universitas Pendidikan Indonesia, Indonesia \\ ${ }_{2}$ Universitas Negeri Jakarta, Indonesia
}

\section{Article Info}

Article history:

Received: 20 Desember 2020;

Accepted: 26 February 2021;

Published: 01 March 2021

Keywords:

Online synchronous learning; Experiences; Higher education students.

\begin{abstract}
This study delivers new insights on students' experiences who have studied their courses at least one semester during the Covid-19 Pandemic. We collected 199 respondents and analyzed the result of the questionnaire. The first finding is that students rather use discussions as a method to conduct online learning in classes. Students also would prefer both methods (asynchronous and synchronous) during online learning. We categorized students' learning experiences into intimacy and connection, supports, coordination and collaboration, technical difficulties, and traits. This study concludes that whole experiences about online synchronous learning did not change, except for the lack of personal support from lecturers when students face difficulties in certain subjects and hardware malfunction during classes. We recommend that lecturers pay more attention to students with less comprehension ability. We also recommend that lecturers run more creative ways other than lecturing in classes and limit lecturing time to decrease boredom.
\end{abstract}

\begin{tabular}{l} 
Abstrak \\
\hline Penelitian ini memberikan wawasan baru tentang pengalaman \\
Mahasiswa yang telah mempelajari mata kuliahnya minimal satu \\
semester selama Pandemi Covid-19. Kami mengumpulkan 199 responden \\
dan menganalisis hasil kuesioner. Temuan pertama, siswa akan \\
menggunakan diskusi sebagai metode untuk melakukan pembelajaran \\
daring di kelas. Siswa juga lebih suka asynchronous dan synchronous \\
selama pembelajaran daring. Penelitian ini mengkategorikan \\
pengalaman belajar siswa ke dalam keintiman dan koneksi, dukungan, \\
koordinasi dan kolaborasi, kesulitan teknis, dan sifat-sifat. Penelitian ini \\
menyimpulkan bahwa seluruh pengalaman tentang pembelajaran \\
synchronous daring tidak berubah, kecuali kurangnyadukungan pribadi \\
dari dosen ketika mahasiswa menghadapi kesulitan dalam mata \\
pelajaran tertentu dan kerusakan perangkat keras selama kelas. Kami \\
menyarankan agar dosen lebih memperhatikan mahasiswa dengan \\
kemampuan pemahaman yang lebih sedikit. Kami juga menyarankan \\
agar dosen mengimplementasikan cara yang lebih kreatif selain \\
mengajar di kelas dan membatasi waktu kuliah untuk mengurangi \\
kebosanan.
\end{tabular}

How to Cite:

Rasto, R., Muhidin, S. A., Inayati, T., \& Marsofiyati, M. (2021). University Student's Experiences with Online Synchronous Learning during Covid-19. Jurnal Pendidikan Ekonomi \& Bisnis, 9(1), 34-43. https://doi.org/10.21009/JPEB.009.1.4 


\section{INTRODUCTION}

Covid-19 Pandemic in the world disrupts how the world works, including the education process. Schools and higher education institutions must think of ways to work on the education process without teaching students face-to-face (Zhang et al, 2020; Karalis, 2020; Pather et al., 2020). Thus, they changed to online learning drastically from the beginning of the year 2020. Switching from offline learning to online learning, especially in developing countries, may not be as smooth as indeveloped countries, although in some cases, several developing countries could transform smoothly (Basilaia \& Kvavadze, 2020). Lecturers are more reluctant to use an online platform as a learning medium. Students often cannot learn as much as they learn in offline classes, and higher education institutions or schools face many other obstacles.

In higher education institutions, the most affected stakeholders are students. The knowledge transfer becomes an issue when learning method changes. Different from traditional classrooms, online learning is divided into two types: synchronous and asynchronous. The synchronous method is online face to face learning with video conference platforms. The asynchronous method allows students to learn the materials by themselves. Lecturers give students assignments, videos, PowerPoint, or other materials for the learning process in the asynchronous method. With such differences, students could have either positive or negative experiences during online learning.

While universities already included blended learning (Hastiea et al., 2010), or a combination of asynchronous and synchronous learning (Young et al., 2014) before the Pandemic, online synchronous learning could potentially pose problems for students. Students may be less attentive when studying elsewhere than in class. We also considered whether students could still develop their soft skills when participating in online classrooms. Therefore, this study observes and evaluates students' experiences during online synchronous learning. If online synchronous learning receives positive feedback from students, universities could continue with the flexibility of learning. If the students perceive negatively, universities must seek alternatives or improve the quality of online synchronous learning to generate similar results in offline synchronous learning. This study focused on the students' points of view and experiences, even though many studies focused on other stakeholders' points of view. The study's limitation is that it did not compare whether online synchronous learning is better than offline synchronous learning due to the absence of data collection during Covid-19 Pandemic.

Before Pandemic hit, many cases used the combination of online and offline synchronous learning. Hastiea et al. (2010) simulating nine modes of learning by online and offline synchronous approaches reported that flexibility from teachers and students is considered the most preferable. These results are in line with findings of a study by López-Pérez et al. (2011) that blended learning had positive effects on increasing students' grades and lowering the number of dropout students. Nonetheless, full online synchronous learning has not been conducted in all universities. It has been conducted as part of an experiment to measure its effects compared to a traditional class. Switching to online learning requires teachers to comprehend the system, process, design, and advantages and disadvantages of online learning, which in turn will lead to a successful transition from a traditional class to online learning (Keengwe \& Kidd, 2010).

Porter et al. (2014) make three categorizations on blended learning adaptations: strategy, structure, and support by interviewing multiple educational institutions. In terms of strategy, blended learning's vision and structure needed to be reviewed by many stakeholders so that there were no discrepancies in the implementation. In terms of structure, institutions must provide adequate infrastructures for blended learning adaptation. Furthermore, support for blended learning could be achieved through training and technical support for teachers, which is also recommended in the area of structure. Therefore, technical and teaching training would be significant to provide students with positive learning experiences (Kim et al., 2011).

Different approaches to online synchronous learning have been proposed by many education researchers. Warden et al. (2013) researched the result of distance learning using video conference or online chat platform and concluded that distance learning's main problem leads to students' behavior rather than technological difficulties. Nevertheless, online synchronous learning was considered successful. 
In Covid-19 Pandemic, education institutions are forced to take drastic measures and switch sessions into full online learning. However, some institutions in rural areas lag behind institutions in city areas. Warden et al. (2013) and Hodges et al. (2020) differentiate online learning that has existed from a few years ago with "emergency remote teaching." They argue that emergency remote teaching, due to natural disaster or other sudden change, has a structure that would return to the usual condition when the disaster finishes. However, the strategy may continue to be applied in emergency states in the future. A similar result was also found in in Adedoyin \& Soykan (2020), study that online learning is more sustainable and has a reliable infrastructure as well as a hybrid teaching approach.

Dhawan (2020), conducted a study using SWOC analysis to evaluate online learning. The results indicated that mastering and focusing on technology infrastructure are essential factors in education during the Covid-19 pandemic. Yet, in developing countries, specifically in rural areas, availability of such infrastructure is a challenge. A study conducted in Pakistan shows that issues in rural areas also include monetary issues, face to face connectivity, response, and the absence of physical classrooms (Adnan, 2020). Likewise, slow connection is another issue faced by students as shown by a study conducted in China (Demuyakor, 2020). Whether online learning generates different results from students' experience or not, a study by Gonzalez et al. (2020) conducted before the Covid-19, shows that online learning positively influences students' learning experiences. The results of the study indicate that students participating in online learning before Covid-19 achieved better grades. Students also experienced an efficient way of learning in an online learning environment. This finding resonates with a study result by López-Pérez et al. (2011). Despite positive outcomes, online learning for students residing in a less fortunate area with the low adaptation of technology may have obstacles in achieving good grades during this time. This argument is supported by significant evidence that show differences between students in the city and countryside (Mulenga \& Marbán, 2020) and students' preferences to have face-to-face learning sessions to achieve similar comprehensions and good communication with the lecturers or other students (Paechter \& Maier, 2010).

Suggest that students preferred face-to-face learning than online learning. In developing countries such as Indonesia, internet access, monetary issues, and online learning infrastructure often become problems (Allo, 2020). In Malaysia (Chung et al., 2020), students are reluctant to continue online learning when the Pandemic is over, and they could return to normal activities. These studies show the importance of capturing students' perspective. This study, therefore, aims to investigate how university students perceive preferences on online learning because every region has different infrastructures and accessibility to conduct learning online. This study intends to open possibilities of new methods of learning that could be more appropriate and accessible for our respondents.

\section{METHOD}

This exploratory study collected data through a questionnaire that was distributed in November 2020. Respondents involved in the study were students who experienced online synchronous learning for at least one semester, especially during Pandemic in developing countries. Data collected were analysed using exploratory analysis to develop its indicators informed by previous studies and compared them to Indonesian context. As a result, we collected 199 respondents and analyzed their demographic and description of their online synchronous learning experiences. This study also provided 18 parameters to gain perspectives from students. These parameters are adopted from previous studieson this topic (Park \& Bonk, 2007; Moallem, 2015; Hrastinski, 2008) and were evaluated using the Likert Scale from 1 ("do not agree") and 5 ("very much agree"). Then, we draw conclusions based on categories that consist of 18 indicators mentioned in table 1. 
Table 1. Indicators and Sources

\begin{tabular}{|c|c|c|}
\hline No. & Indicators & Source \\
\hline 1 & $\begin{array}{l}\text { I perceive direct support and various perspectives during } \\
\text { learning }\end{array}$ & Park \& Bonk (2007) \\
\hline 2 & I have close connections with other students & $\begin{array}{l}\text { Park \& Bonk (2007) \& } \\
\text { Moallem (2015) }\end{array}$ \\
\hline 3 & I have close connections with lecturers & $\begin{array}{l}\text { Park \& Bonk (2007) \& } \\
\text { Moallem (2015) }\end{array}$ \\
\hline 4 & I receive supports related to class assignments from lecturers & Park \& Bonk (2007) \\
\hline 5 & I could ask or answer questions related to topic well & Park \& Bonk (2007) \\
\hline 6 & I could easily share information & $\begin{array}{l}\text { Park \& Bonk (2007) \& } \\
\text { Hrastinski (2008) }\end{array}$ \\
\hline 7 & I could express my ideas or opinions & $\begin{array}{l}\text { Park \& Bonk (2007) \& } \\
\text { Hrastinski (2008) }\end{array}$ \\
\hline 8 & $\begin{array}{l}\text { I perceive special attention from lecturers when I face } \\
\text { difficulties }\end{array}$ & Park \& Bonk (2007) \\
\hline 9 & I read requirements and guidelines prior to lessons & Park \& Bonk (2007) \\
\hline 10 & I allocate assignment and coordination collectively & $\begin{array}{l}\text { Park \& Bonk (2007) \& } \\
\text { Hrastinski (2008) }\end{array}$ \\
\hline 11 & could negotiate and solve conflicts & Hrastinski (2008) \\
\hline 12 & $\begin{array}{l}\text { I review my own or other students' assignments discussed } \\
\text { during lessons }\end{array}$ & Park \& Bonk (2007) \\
\hline 13 & $\begin{array}{l}\text { I prepare feedbacks and suggestions to team member's } \\
\text { assignment well }\end{array}$ & Park \& Bonk (2007) \\
\hline 14 & I became self-dependent & Moallem (2015) \\
\hline 15 & I could collaborate with other students & Moallem (2015) \\
\hline 16 & I could not conduct a discussion or give feedback well & Park \& Bonk (2007) \\
\hline 17 & I often have problems with network connection & Park \& Bonk (2007) \\
\hline 18 & I often have problems with audio and other parts & Park \& Bonk (2007) \\
\hline
\end{tabular}

Based on these parameters, we drew four categories that included intimacy and connection, coordination and collaboration, technical difficulties, and students' traits. These categories were analyzed and generated from thesurvey results. Finally, conclusions and recommendations were made specifically for future online synchronous learning approach.

\section{RESULTS AND DISCUSSION}

Respondents involved in the study were $62 \%$ from Indonesia, 27\% from Malaysia and 11\% others were unknown. From Indonesian respondents, most of them are currently studying in National University, which means that most graduates from the University will become teachers in schools. Thus, speaking out about their experiences using an online synchronous or asynchronous method is very useful for future improvements.

Table 2. Proportion of Students' year

\begin{tabular}{ccc}
\hline Percentage & Students' year & Count \\
\hline 27 & First year & 54 \\
22 & Second year & 44 \\
37 & Third year & 73 \\
14 & Fourth year & 28 \\
100 & Total & 199 \\
\hline
\end{tabular}

The majority of respondents were in their third year (37\%), followed by the first year, the second year, and the fourth year. Third-year students were considered ideal to be the primary 
respondents because they had experienced both online and offline learning so that their opinions would generate fruitful results.

Several fundamental questions are adopted from Perveen (2016), who studied the experience of teaching English language using synchronous and asynchronous modes. The survey used in this study asked the respondents whether they understood synchronous or asynchronous teaching methods. Surprisingly, 18 percent answered 'no', which indicates that the respondents were exposed to different terminology instead of synchronous/asynchronous. We drew this conclusion because, during the Covid-19 Pandemic, lessons and classes were conducted online. After explaining the definitions to respondents, they were asked about the time duration considered ideal to conduct a synchronous session.

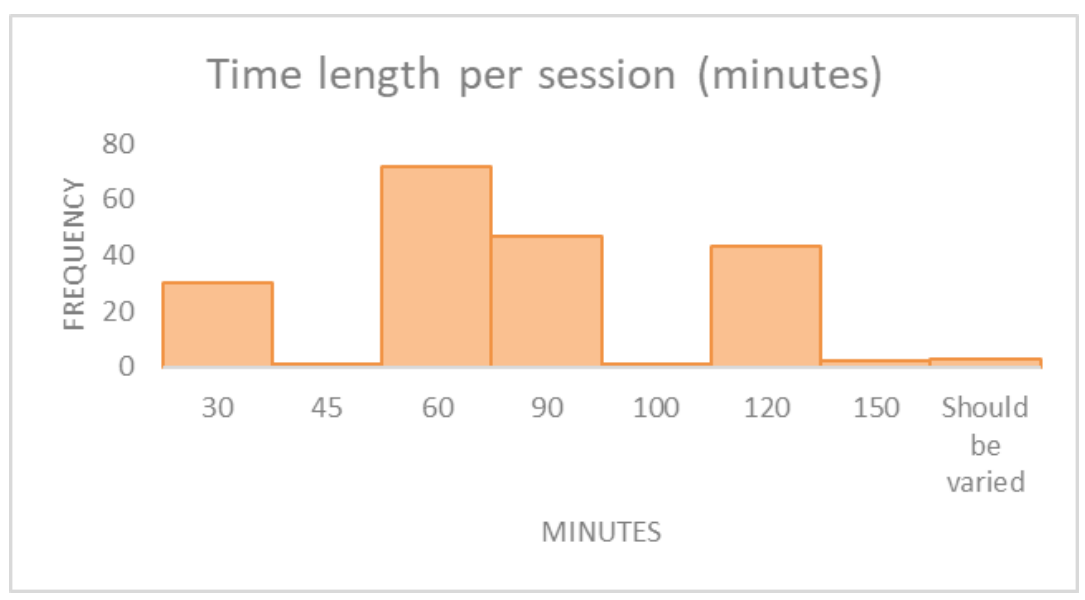

Figure 1. Ideal Synchronous Session Time

According to figure 1, the ideal time chosen by respondents is 60 minutes. In Indonesia, the duration of each session ( 1 credit hour) is 50 minutes. Typically, one subject last for about two credit hours which means that it takes 100 minutes or more. The second preferable duration is 90 minutes, followed by 120 minutes. The least preferences are 45 and 100 minutes. Our analysis in this finding is that this relates to the students' attention span in class. Students have an attention span of $10-$ 15 minutes in class before they experience boredom or decreasing concentration (Bradbury, 2016; Siegenthaler \& Caneday, 2003; Geri et al., 2017). In order to manage this problem, modifying approaches in class is essential to increase students' attention span (Geri et al., 2017).

The previous outcome leads to our next question to the respondents. We provided the respondents with common types of teaching methods preferable by students while having synchronous learning. The result is displayed Table 3.

Table 3. Ideal Methods for Synchronous Teaching

\begin{tabular}{lll}
\hline Percentage & Method for synchronous teaching & Number \\
\hline 19 & Discussion & 38 \\
11 & Discussion \& lectures & 22 \\
1 & Discussion, lectures, roleplay & 1 \\
12 & Discussion \& presentation & 23 \\
16 & Discussion, presentation, lectures & 32 \\
8 & All options & 15 \\
4 & Discussion, presentation, roleplay & 8 \\
4 & Discussion, roleplay & 8 \\
12 & Lectures & 24 \\
1 & Lectures \& roleplay & 2 \\
4 & Presentation & 8 \\
\hline
\end{tabular}




\begin{tabular}{lll}
\hline Percentage & Method for synchronous teaching & Number \\
\hline 5 & Presentation \& lectures & 9 \\
2 & Presentation, lectures, roleplay & 3 \\
1 & Presentation \& roleplay & 1 \\
2 & Roleplay & 4 \\
1 & Others & 1 \\
100 & Total & 199 \\
\hline
\end{tabular}

Students considered discussion as the most ideal activity. We can suggest this method to increase students' engagement in the class, mainly if the lesson is conducted using the synchronous method. The second highest is a combination of discussion, presentation, and role-play. Interestingly enough, lectures only become the third preferable method by our respondents, concluding that there should be more creative and innovative ways of teaching students other than lectures only. Meanwhile, the least chosen methods of learning based on respondents' answers included discussion, lectures, roleplay, lectures and roleplay, presentation and roleplay, and one respondent chose others.

Students' participation in synchronous learning indicates positive feedback. It is evident from 83 percent of the respondents saying that they were being active during synchronous learning. Even though we do not have any comparison to other studies on asynchronous learning, synchronous learning was still considered important because it measures the capabilities of students directly during session from their participation. On the other hand, asynchronous learning only requires little communication or dialogue between students and lecturers. Hence, comprehending students' abilities on the topic might be less than that when students are experiencing synchronous learning. However, asynchronous cannot be removed completely from the course's methods of teaching. This argument was supported by 81 percent of the respondents considering both approaches (synchronous and asynchronous) the most effective approach in teaching. The survey also show that 14 percent said only synchronous approach was the most effective, while the rest 5 percent mentioned only asynchronous approach.

In the methodology, we combined several parameters synthesized from previous studies to complement the variables that would show the students' experiences during pandemic teaching. This section discusses these experiences based on the following categories: intimacy and connection, coordination and collaboration, technical difficulties, and students' traits. The intimacy and connection category consists of two parameters. The support consists of three parameters: coordination and collaboration, consisting of five parameters. Technical difficulties consist of two parameters, and traits consist of six parameters. Since the data was meant to be Likert scale, we treat it as ordinal data.

Table 4. Parameters Median Score

\begin{tabular}{lll}
\hline \multicolumn{1}{c}{ No. } & \multicolumn{1}{c}{ Indicator } & Median \\
\hline 1 & I perceive direct support and various perspectives & 4 \\
& during learning & 4 \\
2 & I have intimate connections with other students & 3 \\
3 & I have intimate connections with lecturers & 4 \\
4 & I receive supports related to class assignments from & 4 \\
& lecturers & 4 \\
5 & I could ask or answer questions related to topic well & 4 \\
6 & I could easily share information & 3 \\
7 & I could express my ideas or opinions & 4 \\
8 & I perceive special attention from lecturers when I face & 4 \\
& difficulties & 4 \\
10 & I read requirements and guidelines prior to lessons & I allocate assignment and coordination collectively
\end{tabular}




\begin{tabular}{lll}
\hline No. & \multicolumn{1}{c}{ Indicator } & Median \\
\hline 11 & I could negotiate and solve conflicts & 4 \\
12 & $\begin{array}{l}\text { I review my own or other students' assignments } \\
\text { discussed during lessons }\end{array}$ & 4 \\
13 & $\begin{array}{l}\text { I prepare feedbacks and suggestions to team member's } \\
\text { assignment well }\end{array}$ & 4 \\
14 & I became self-dependent & 4 \\
15 & I could collaborate with other students & 4 \\
16 & I could not conduct a discussion or give feedback well & 3 \\
17 & I often have problems with network connection & 4 \\
18 & I often have problems with audio and other parts & 3 \\
\hline
\end{tabular}

Two parameters are in intimacy and connection in Table 3. "I have a close connection with other students" and "I have close connections with lecturers" fall into this category with a median of 4 for the first and 3 for the latter. This result indicates that students have more connection with other students compared to their lecturers. Learning using synchronous methods online still generates positive experiences on being close with other students. However, students perceived less intimacy with their lecturers, albeit not in the lowest score. The proportions indicate that less than half of respondents choose the majority score.

Five parameters in coordination and collaboration category included allocating assignment and coordination collectively; reviewing own and others' assignments during lessons; preparing feedbacks and suggestions to team assignment; collaborating with other students, and unable to conduct a discussion or give feedback. The first four parameters indicate students' positive experiences during synchronous online learning. Meanwhile, the last parameter, where the statement showed negative experiences, has neutral responses. The answers imply that students collaborated with other students well. Coordination during online synchronous learning is perceived positive, despite issues encountered by some respondents. Students also reported that they had no difficulties in preparing feedbacks and having a discussion during sessions. However, we detected some unsatisfaction from students that they could not conduct a discussion or handing feedback during sessions. This is most likely due to technical problems since there were no crucial difficulties in building intimacy.

Concerning the technical difficulties faced in online synchronous learning, especially during Pandemic, respondents mostly faced difficulties in internet connections. For instance, in Indonesia, the internet connection may not be easily accessible in inland or rural areas due to uneven network development. Therefore, there should be more considerations for students who live with a limited network connection. Having difficulties in audio and other devices depend on the condition of the hardware. Hence, it appeared that respondents tend to state neutral compared to difficulties in network connections.

As an educational institution, students are not only expected to understand technical or theoretical skills, but they also need to have traits embedded in each course they study. Therefore, we need to analyze whether students' traits gained from class sessions (offline) also apply in online class sessions. Parameters included in this category are: (1) Ability to ask or answers questions related to topic; (2) Ability to share information; (3) Ability to express ideas or opinions; (4) Reading requirements and guidelines prior to sessions; (5) Ability in negotiation and solving conflicts, and (6) Becoming self-dependent.

The results show that students have similar traits in offline and online synchronous sessions. This finding gives significant insights into the lack of face to face method that would generate more negative effects on students' traits. Online synchronous learning would use more media to conduct activities that support the development of students' traits. 


\section{CONCLUSIONS AND SUGGESTION}

Due to the pandemic, the learning process in higher education institutions has changed drastically. Online learning must be conducted to continue the learning process in these institutions. Online synchronous learning substitutes offline synchronous learning. However, it is difficult to comprehend whether this type of learning gives more detrimental or incremental results. Using a survey involving students who have experienced online synchronous learning, this study gained new perspectives on students' experiences. The respondents claimed that they would prefer both methods (synchronous and asynchronous) in every course. They also suggested that 60 minutes would be the ideal time for each online session, and they would mostly prefer discussion and other types of activity while doing online synchronous learning. We categorized the parameters into five types: intimacy and connections, supports, coordination and collaboration, technical difficulties, and traits. Students claimed that they still keep up with traits positively. As for other categories, students had positive experiences by conducting online synchronous learning, too.

Nevertheless, students felt that they did not have close connection while doing online synchronous learning with their lecturers. They also claimed that they did not receive special attention when they face difficulties from their lecturers. Another important finding in this study is that students often had difficulties in network connection rather than audio and other devices. This study would recommend lecturers to be more personally attentive to students especially students with less comprehension skills, since it is common that not having physically face to face communication with students may have negative impact to students' performance. We also recommend that lecturers would use more creative ways other than only lecturing in online classes, and limit online time for lecturing in order to decrease boredom.

\section{REFERENCES}

Adedoyin, O. B., \& Soykan, E. (2020). Covid-19 pandemic and online learning: the challenges and opportunities. Interactive Learning Environments, 1-13. https://doi.org/10.1080/10494820.2020.1813180

Adnan, M. (2020). Online learning amid the COVID-19 pandemic: Students perspectives. Journal of Pedagogical Research, 1(2), 45-51. https://doi.org/10.33902/jpsp.2020261309

Allo, M. D. G. (2020). Is the online learning good in the midst of Covid-19 Pandemic? The case of EFL learners. Jurnal Sinestesia, 10(1), 1-10.

Basilaia, G., \& Kvavadze, D. (2020). Transition to Online Education in Schools during a SARS-CoV2 Coronavirus (COVID-19) Pandemic in Georgia. Pedagogical Research, 5(4), 1-9. https://doi.org/10.29333/pr/7937

Bradbury, N. A. (2016). Attention span during lectures: 8 seconds, 10 minutes, or more? Advances in Physiology Education, 40(4), 509-513. https://doi.org/10.1152/advan.00109.2016

Chung, E., Subramaniam, G., \& Dass, L. C. (2020). Online Learning Readiness among University Students in Malaysia amidst COVID-19. Asian Journal of University Education, 16(2), 46-58. https://doi.org/10.24191/ajue.v16i2.10294

Demuyakor, J. (2020). Coronavirus (COVID-19) and Online Learning in Higher Institutions of Education: A Survey of the Perceptions of Ghanaian International Students in China. Online Journal of Communication and Media Technologies, 10(3), 1-9. https://doi.org/10.29333/ojcmt/8286

Dhawan, S. (2020). Online Learning: A Panacea in the Time of COVID-19 Crisis. Journal of Educational Technology Systems, 49(1), 5-22. https://doi.org/10.1177/0047239520934018 
Geri, N., Winer, A., \& Zaks, B. (2017). A learning analytics approach for evaluating the impact of interactivity in online video lectures on the attention span of students. Interdisciplinary Journal of E-Learning and Learning Objects, 13(1), 215-228. https://doi.org/https://doi.org/10.28945/3875

Gonzalez, T., De la Rubia, M. A., Hincz, K. P., Comas-Lopez, M., Subirats, L., Fort, S., \& Sacha, G. M. (2020). Influence of COVID-19 confinement on students' performance in higher education. PLoS ONE, 15(10), 1-23. https://doi.org/10.1371/journal.pone.0239490

Hastiea, M., Hung, I. C., Chen, N. S., \& Kinshuk. (2010). A blended synchronous learning model for educational international collaboration. Innovations in Education and Teaching International, 47(1), 9-24. https://doi.org/10.1080/14703290903525812

Hodges, C., Moore, S., Lockee, B., Trust, T., \& Bond, A. (2020). The difference between emergency remote teaching and online learning. Educause review, 27, 1-12.

Hrastinski, D. (2008). Asynchronous and synchronous e-learning. Educause Quarterly, 31(4), 51-55.

Karalis, T. (2020). Planning and evaluation during educational disruption: Lessons learned from COVID-19 pandemic for treatment of emergencies in education. European Journal of Education Studies.

Keengwe, J., \& Kidd, T. (2010). Towards best practices in online learning and teaching in higher education. MERLOT Journal of Online Learning and Teaching, 6(2), 533-541.

Kim, J., Kwon, Y., \& Cho, D. (2011). Investigating factors that influence social presence and learning outcomes in distance higher education. Computers and Education, 57(2), 1512-1520. https://doi.org/10.1016/j.compedu.2011.02.005

López-Pérez, M. V., Pérez-López, M. C., \& Rodríguez-Ariza, L. (2011). Blended learning in higher education: Students' perceptions and their relation to outcomes. Computers and Education, 56(3), 818-826. https://doi.org/10.1016/j.compedu.2010.10.023

Means, B., Toyama, Y., Murphy, R., Bakia, M., \& Jones, K. (2009). Evaluation of evidence-based practices in online learning: A meta-analysis and review of online learning studies.

Moallem, M. (2015). The impact of synchronous and asynchronous communication tools on learner self-regulation, social presence, immediacy, intimacy and satisfaction in collaborative online learning. The Online Journal of Distance Education and E-Learning, 3(3), 55-77.

Mulenga, E. M., \& Marbán, J. M. (2020). Prospective teachers' online learning mathematics activities in the age of COVID-19: A cluster analysis approach. Eurasia Journal of Mathematics, Science and Technology Education, 16(9), 1-9. https://doi.org/10.29333/EJMSTE/8345

Paechter, M., \& Maier, B. (2010). Online or face-to-face? Students' experiences and preferences in elearning. The internet and higher education, 13(4), 292-297.

Park, Y. J., \& Bonk, C. J. (2007). Synchronous Learning Experiences: Distance and Residential Learners' Perspectives in a Blended Graduate Course. Journal of Interactive Online Learning, 6(3), 245-264. https://doi.org/10.7169/facm/1308749125

Pather, N., Blyth, P., Chapman, J. A., Dayal, M. R., Flack, N. A., Fogg, Q. A., ... \& Lazarus, M. D. (2020). Forced disruption of anatomy education in Australia and New Zealand: An acute response to the Covid-19 pandemic. Anatomical sciences education, 13(3), 284-300.

Perveen, A. (2016). Synchronous and Asynchronous E-Language Learning: A Case Study of Virtual University of Pakistan. Open Praxis, 8(1), 21-39. https://doi.org/10.5944/openpraxis.8.1.212

Porter, W. W., Graham, C. R., Spring, K. A., \& Welch, K. R. (2014). Blended learning in higher education: Institutional adoption and implementation. Computers and Education, 75, 185-195. https://doi.org/10.1016/j.compedu.2014.02.011 
Siegenthaler, K. L., \& Caneday, L. (2003). Phillip C. Wankat. The Effective, Efficient Professor Teaching, Scholarship and Service . SCHOLE: A Journal of Leisure Studies and Recreation Education, 18(1), 95-97. https://doi.org/10.1080/1937156x.2003.11949512

Warden, C. A., Stanworth, J. O., Ren, J. B., \& Warden, A. R. (2013). Synchronous learning best practices: An action research study. Computers and Education, 63(2013), 197-207. https://doi.org/10.1016/j.compedu.2012.11.010

Young, T. P., Bailey, C. J., Guptill, M., Thorp, A. W., \& Thomas, T. L. (2014). The flipped classroom: A modality for mixed asynchronous and synchronous learning in a residency program. Western Journal of Emergency Medicine, 15(7), 938-944. https://doi.org/10.5811/westjem.2014.10.23515

Zhang, S. X., Wang, Y., Rauch, A., \& Wei, F. (2020). Unprecedented disruption of lives and work: Health, distress and life satisfaction of working adults in China one month into the COVID-19 outbreak. Psychiatry research, 288, 112958. 